\title{
Biogas Synthesis from Leather Industry Solid Waste in Pakistan
}

\author{
Madiha Ijaz', Amtul Bari Tabinda², Sajid Rashid Ahmad", \\ Waheed Ullah Khan ${ }^{1 *}$, Nasim Ahmad Yasin ${ }^{3}$ \\ ${ }^{1}$ College of Earth and Environmental Sciences, University of the Punjab, Lahore, Pakistan \\ ${ }^{2}$ Sustainable Development Study Centre, Government College University Lahore, Pakistan \\ ${ }^{3}$ Senior Superintendent Garden, University of the Punjab, Lahore, Pakistan
}

Received: 8 January 2019

Accepted: 2 July 2019

\begin{abstract}
About $80 \%$ of raw material of the leather industry ends up in waste, which poses a great problem for waste management. During the current study, economical and ecofriendly techniques for conversion of tannery waste into biogas were evaluated. Fats, shavings and dried sludge showed $50 \%, 65 \%$ and $61 \%$ organic content and $68 \%, 45 \%$ and $9.6 \%$ moisture content, respectively. Dried sludge, pre-tanning waste (fats and shavings) and manure were digested either alone or in different combinations through amber glass bottles. The temperature was maintained from $32^{\circ} \mathrm{C}$ to $35^{\circ} \mathrm{C}$ by insulating digesters with sand at $\mathrm{pH} 6.8$ to 7.5 . The maximum amount of biogas $(1623 \pm 26.1 \mathrm{ml} / \mathrm{kg})$ was observed by digesting equal proportions of manure and dried sludge. The results depicted that $473 \pm 9.19 \mathrm{ml}$ of biogas was biosynthesized from $1 \mathrm{~kg}$ of sample comprising $25 \%$ pre-tanning waste and $75 \%$ manure.
\end{abstract}

Keywords: organic waste, biogas, tannery waste management, home scale digester, manure

\section{Introduction}

Sialkot, a small city in Pakistan, is exporting leather products mainly to Europe. At present there are approximately 248 tanneries in the city, out of which 169 are small, 79 are medium and 9 are large. But all these tanneries are scattered and have poor or zero waste management planning. Solid wastes such as fine leather particles, residues from numerous chemical discharges, reagents from different waste bodies, fleshing residues, large pieces of leather cuttings, trimmings, solid hair conglomerates, shavings and

*e-mail: waheedenviro@gmail.com remnants of paper bags originate during all stages of leather making [1]. Approximately $850 \mathrm{~kg}$ per $1000 \mathrm{~kg}$ is generated as solid waste in leather processing, and just $150 \mathrm{~kg}$ of the raw material becomes useable leather. Waste generated in the tannery consists of $57-60 \%$ fleshing, 35-40\% chrome shavings/chrome splits, 5-7\% skin trimmings and $2-5 \%$ hair [2]. Over 80 per cent of the organic pollution load, biological oxygen demand (BOD) emanates from the beam-house (pre-tanning); much of this pollution load comes from degraded skin and hair material.

Anaerobic digestion (AD) is a breakdown of complex organic matter by microorganisms in absence of oxygen [3]. Nevertheless, anaerobic digestion is an economical and eco-friendly technique for the production of biogas from different industrial wastes [4]. Hence, 
the anaerobic digestion technique assists in reducing environmental pollution through the generation of biogas from leather industry wastes [5]. In this process, decomposition of organic matter generates bio-fertilizer and biogas consisting of methane, carbon dioxide and trace amounts of hydrogen, carbon monoxide, nitrogen, oxygen and hydrogen sulfide [6]. Production of biogas by anaerobic digestion and from tannery solid waste can be used to provide methane supply to the tanneries, leading to energy recovery from the waste and hence lowering production costs [7]. Most tanneries have installed wastewater treatment plants and are treating their wastewater ending in sludge having considerable organic content [8].

In the present study, the tanneries used for sampling are selling their fats to the small-scale factories that use these fats to generate glue, which is further used in cosmetics preparation. The waste management departments of tanneries are selling these fats at the rate of RS 30,000 to RS 50,000 throughout the year, which is quite low (personal communication). Since the fats have a high percentage of organic content, it would be more beneficial for the tanneries to either sell these fats at a high price or to utilize them for biogas production. Similarly, most of the tanneries in Sialkot are also selling the residues of shavings to the small factories, where it is used as raw material for manufacturing carpets, pillows and mattresses. The bulk of waste shavings from a factory are sold at the rate of RS 25,000 to RS 35,000 for the whole of the year (personal communication). Tanneries produce a large amount of these waste shavings, which are again being sold at a very low price. Due to high organic content, about $61 \%$, it would be wiser to utilize shavings in biogas production rather than selling them at very low cost. The present study was carried out in order to assess the biogas production from dried sludge of tannery waste water plant and from pre-tanning waste separately.

\section{Material and Methods}

\section{Study Area}

We selected Sialkot district, located in Punjab province, because it is famous for the seasonal tanning industry. Most of the industries of the study area start working in March, when it becomes feasible to work, and after Eid-ul-Azaha, when animal hide becomes readily available.

Three tanneries were selected for collecting solid waste. Two samples were of fats and shavings respectively and the third sample was dried sludge collected from the existing pre-tanning waste. Fats and shavings are collectively termed tanning waste, which has a great potential for biogas generation [9]. The dried (under sunlight) sludge at an existing water treatment plant and the pre-tanning waste (fats and shavings) were targeted to calculate biogas production capacity.

\section{Collection and Pretreatment of Samples}

The sample of pre-tanning (fats and shavings) and dried sludge wastes were collected (randomly and unweight) from different locations and washed onsite thrice. The purpose of washing was removal of salts and other tanning material applied to hides for processing. Washing is found to be a reliable method for removal of salts used for tanning hides. These washed samples were collected in transparent zipper bags of $3 \mathrm{~kg}$ capacity and the category of each kind of waste was labeled. Samples of pre-tanning waste were stored at $4^{\circ} \mathrm{C}$ in a laboratory to keep them fresh [10]. The dried sludge had a lot of concrete particles and debris that were removed manually.

\section{Measuring Sample Characteristics}

Characteristics of samples such as $\mathrm{pH}$, temperature, organic content, moisture and content, etc., were measured to check their suitability for anaerobic digestion [11]. The quantity of biogas remains constantly proportional to the percentage of organic content in the targeted substance [12]. And to check this organic content the collected samples were weighed in crucible dishes separately and dried in an oven overnight at $105^{\circ} \mathrm{C}$. After being taking out of the oven, the samples were weighed again and kept in a muffle furnace for two hours at $550^{\circ} \mathrm{C}$ and weighed once again after cooling in desiccators. The weight difference was calculated to determine the percentage of organic content.

Each weighed sample was placed in a pre-weighed crucible dish and these were weighed collectively. After weighing, the dishes were placed in an oven and dried overnight at $105^{\circ} \mathrm{C}$. Once again these dried dishes were weighed and the weight difference was calculated to analyze the moisture content. The formula for moisture content is:

$$
\text { i) Moisture }(\theta)=\frac{\text { wet sample }(\mathrm{g})-\text { dry sample }(\mathrm{g})}{\text { Dry sample }(\mathrm{g})}
$$

ii) Dry sample $(g)=[1 /(1+\Theta / 100)] \times$ wet sample $(g)$

iii) Moisture content $=\frac{\text { wet soil }(\mathrm{g})}{\text { Dry soil }(\mathrm{g})}$

Sodium was determined using flame photometer and chloride concentrations were measured using the titration method. Electrical conductivity was measured using digital a conductivity meter (EC300 YSI, USA).

\section{Assessing Heavy Metal}

The heavy metal chromium (Cr-III) was also determined from tannery solid waste samples (shavings, fats and sludge) with the help of an atomic absorption spectrophotometer. 


\section{Slurry Formation}

The collected samples were crushed into fine particles and mixed with a mechanical stirrer with water $(70 \%)$ and fresh cow dung in different ratios to prepare the samples for anaerobic digestion. Mainly samples were divided into two categories: one of dried sludge and other a mixture of fats and shavings in equal quantities. Slurry formation needs special attention as proper mixing ensures particle contact with each other, hence the homogenous mixture was prepared by drying, crushing, weighing and mixing the prepared material from samples [13]. Usually the slurry formation is succeeded by drying, weighing and crushing.

\section{Digester Preparation with $\mathrm{pH}$ Monitoring and Biogas Calculation}

The apparatus for anaerobic digestion consists of bottles made up of amber (2.5 liter), plastic bags or box, sand, PVC tubes for biogas collection and transportation, a cork and water holding graduated plastic jars (Fig. 1). This operation is designed following many studies on cheap lab scale operations for anaerobic digestion. Each of the samples was mixed separately with fresh cow dung in different ratios and poured into designed digesters (amber glass bottles) sealed with a cork. Finally the digesters were placed in sand contained in shopping bags and boxes in a temperature-regulated laboratory.

Both types of samples (fats and shavings and dried sludge) were subdivided into 15 samples (one having only manure, one having only a sample and three having manure and samples in different ratios), including replicas, of each on the basis of cow dung concentration. The digesters containing samples of sludge were tagged as "S," where the S1 digester contained sludge and manure in a $1: 1$ ratio (50\% manure and $50 \%$ sludge),

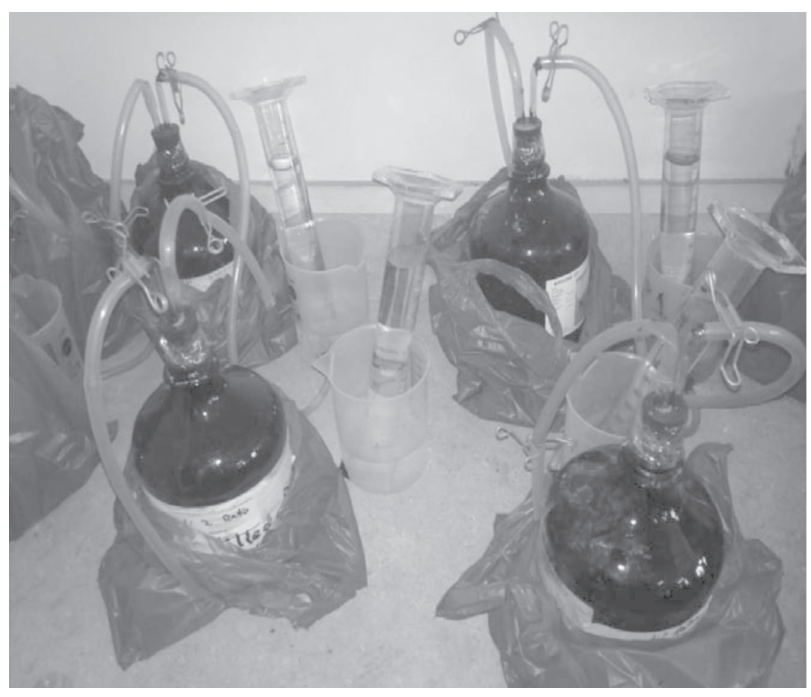

Fig. 1. View of the installation of water replacement method by replica setup of the digesters.
S2 contained sludge and manure at 1:2 (66.7\% manure and $33 \%$ sludge), S3 contained sludge and manure at 1:3 ( $75 \%$ manure and $25 \%$ sludge), S4 contained only sludge with no addition of manure and F5 contained no sludge but only manure. The digesters containing samples of a mixture of fats and shavings were labeled "FS," while the category of pre-tanning (fats and shavings) waste digester FS1 contained fats and shavings and manure at a $1: 1$ ratio (50\% pre-tanning waste and $50 \%$ manure), FS2 contained fats and shavings and manure at 1:2 (33.3\% pre-tanning waste and $66.7 \%$ manure), FS3 contained fats and shavings and manure at 1:3 (25\% pre-tanning waste and $75 \%$ manure), FS4 contained only the fats and shavings with no manure and FS5 had only manure and no fats/shavings.

Regulation of temperature and $\mathrm{pH}$ are important in anaerobic digestion. The $\mathrm{pH}$ of the digester was difficult to monitor as it was an anaerobic digestion system that changes conditions with exposure to oxygen gas from air. However, a replica of every digester was installed and the sample was taken out using a long spatula and its $\mathrm{pH}$ was measured respectively. No sooner did the $\mathrm{pH}$ values show abnormality from the standard values at all stages of anaerobic digestion when we added drops of $\mathrm{NaOH}$ (to increase) and sulfuric acid to lower the $\mathrm{pH}$ of the digesters [14]. Likewise, the temperature of digesters was maintained at $32^{\circ} \mathrm{C}$ to $35^{\circ} \mathrm{C}$ by fixing laboratory temperature in addition to insulating the digesters with sand in order to ensure the consistency of temperature.

The water replacement method was used to measure produced biogas volume during anaerobic digestion. For this purpose, graded plastic jars and graduated cylinders were used to set up the apparatus for the water replacement method [15]. Cylinders of $500 \mathrm{ml}$ capacity were filled with water and submerged in inverted form into the jars already containing a considerable layer of water. The initial level at the inverted top of the cylinder was noted ( $40 \mathrm{ml}$ at bottom) to calculate the gas on a daily basis. The PVC pipes (used for transportation of biogas) were opened in these inverted cylinders and the phenomenon of rising bubbles due to biogas production caused water to move downward out of the cylinders into the jars. It was observed that after the gas generation started it replaced water of sludge digest by $40 \mathrm{ml}$ on average. Hence, the more biogas produced in the digesters replaced more quantity of water in the cylinders.

\section{Data Collection}

All the primary data elucidated in this research was obtained directly from the experiment conducted to assess the amount of biogas and chromium generated from tannery waste. Information was also collected from other relevant and reliable sources in order to observe data about pre-production of biogas and chromium removal from tannery waste. 


\section{Statistical Analysis}

For data analysis we used Statistical Packages for the Social Sciences (SPSS) 16 software and figured out the correlation between the variables, namely sludge and manure in ratio 1:1, sludge and manure in ratio $1: 2$, and sludge and manure in 1:3; fats/shavings and manure in ratio $1: 1$, fats/ shavings and manure in ratio $1: 2$, and fats/ shavings and manure in ratio 1:3. Twotailed analysis was used to evaluate if $p$-value $>\alpha$ where $\alpha=0.05$.

\section{Results and Discussion}

The energy crisis and solid waste management have become very critical issues for the city district government of Pakistan. The waste of the tanneries in Sialkot district is not being disposed of in an appropriate way, leading to emissions of greenhouse gases along with many waterborne diseases. Biogas generation through anaerobic digestion of tannery waste is a cost-effective technique. The phenolics present in leather waste cause environmental pollution. The heating procedures during anaerobic digestion reduce phenolic contents of tannery solid waste and decline its negative impact on environmental health. The economic and environmental concerns have recently enhanced the application of anaerobic digestion for biogas production from leather wastes [16].

In this connection, the solid waste of tanneries, including treated dried sludge (obtained from existing water treatment plant) and pre-tanning waste (fats and shavings), were analyzed for the production of biogas under the anaerobic digestion process by inoculating fermentation bacteria from manure.

\section{Characteristics of Samples}

Different tests were applied on samples of sludge, shavings, fats and manure to check their characteristics in different aspects (different obtained results are also narrated in Table 1). The results showed that fats have $65 \%$ organic content higher than shavings $(61 \%)$, sludge $(50 \%)$ and manure $(47 \%)$. The moisture content of fats was $68.9 \%$ and of shavings was $45 \%$, but the moisture content of sludge was lowest because the sludge was collected from a water treatment plant. Therefore, it was treated and dried, which showed only 9.6\% moisture. Fats gave the highest reading of $\mathrm{pH}$, which was 12.39 compared to shavings (8.14), manure (8.1) and sludge (7.2). The reason for the high $\mathrm{pH}$ of fats may lie in the persistence of salt content even after washing thrice, as some studies prove that fats from tanneries tend to hold some of the salt content even after certain treatments to remove it [17].

The results depicted that the amount of $\mathrm{Cr}$ was found to be $78 \mathrm{mg} \mathrm{kg}^{-1}$ in shavings, $16 \mathrm{mg} \mathrm{kg}^{-1}$ in fats, and $84 \mathrm{mg} \mathrm{kg}^{-1}$ in dried sludge, respectively. Our results regarding the presence of heavy metals in tannery solid waste are congruent with the observations of Koki and Jimoh [18].

\section{Biogas Production from Dried Sludge}

Biogas production can be precipitated by seedling microorganisms in the digester, which works as a fermenter in the digester, and cow dung plays a significant role in this regard [19]. The observed statistics showed a great relationship between sludge and manure for the production of biogas. Calculating the correlations of these variables - sludge and manure 1:1, sludge and manure 1:2 and sludge and manure 1:3 - showed that these variables are strongly correlated because they gave a value of $\mathrm{p}<0.05$.

According to the obtained results, the digester $\mathrm{S} 1$ (50\% sludge and $50 \%$ cow dung) gave the maximum value with average $1623.5 \pm 26.1 \mathrm{ml}$ production of biogas. The net biogas from the digester S3 (25\% sludge and $75 \%$ cow dung) remained second, with an average $1331 \pm 29.6 \mathrm{ml}$ yield of biogas. The values elucidated in Table 2 show that the sample S2 (containing $33.3 \%$ sludge and $66.7 \%$ manure) digester gave the $1250 \pm 12.1 \mathrm{ml}$ of net biogas, which was lowest from the others where the digester S4 (pure sludge with no mixture of cow dung) resulted in no production of biogas. The production of biogas $888.5 \pm 19.0 \mathrm{ml}$ from manure (S5) remained lowest in comparison to its combination with sludge.

The tannery waste contains different organic compounds, and a blend of manure enhances organic matter in this waste. The enhanced organic constituents

Table 1. Characteristics of the samples (sludge, fats and shavings and manure) before slurry formation.

\begin{tabular}{|c|c|c|c|c|c|c|}
\hline \multirow{2}{*}{ Type of Sample } & \multicolumn{7}{|c|}{ Name of parameters } \\
\cline { 2 - 8 } & $\begin{array}{c}\text { Organic content } \\
(\% \text { TS) }\end{array}$ & $\begin{array}{c}\text { Moisture content } \\
(\%)\end{array}$ & $\begin{array}{c}\text { Chloride } \\
(\text { meq/L) }\end{array}$ & $\begin{array}{c}\text { Sodium } \\
(\mathrm{ppm})\end{array}$ & $\begin{array}{c}\text { EC } \\
\text { (electric conductivity, mS/cm) }\end{array}$ & $\mathrm{pH}$ \\
\hline Fats & 65 & 68.9 & 24 & 67.4 & 10.3 & 12.4 \\
\hline Shavings & 61 & 45 & 11 & 131.0 & 24.2 & 8.14 \\
\hline Sludge & 50 & 9.6 & 1.2 & 9.2 & 587 & 7.20 \\
\hline Manure & 47 & 47.7 & 21 & 39.2 & 4.31 & 8.10 \\
\hline
\end{tabular}


Table 2. Net biogas production from samples of tannery sludge.

\begin{tabular}{|c|c|c|}
\hline $\begin{array}{c}\text { Sample } \\
\text { Name }\end{array}$ & $\begin{array}{c}\text { Sludge ratio with } \\
\text { manure }\end{array}$ & $\begin{array}{c}\text { Mean } \pm \text { SD biogas } \\
(\mathrm{ml})\end{array}$ \\
\hline S1 & $1: 1$ & $1623.5 \pm 26.1$ \\
\hline S2 & $1: 2$ & $1250.5 \pm 12.1$ \\
\hline S3 & $1: 3$ & $1331 \pm 29.6$ \\
\hline S4 & $1: 0$ & $00: 00$ \\
\hline S5 & $0: 1$ & $888.5 \pm 19.0$ \\
\hline
\end{tabular}

in manure supplemented tannery waste, and respective higher amount of biogas generation has been reported by some other researchers [20]. Manure contains a number of diversifying microbes. The enhanced biogas production in microbe-inoculated tannery waste has been reported in some recent findings [21].

\section{Biogas Generation from a Mixture of Fats and Shavings}

A homogenous mixture of fats and shavings was prepared by adding both contents in equal quantity. Like sludge, 15 samples with three times replication were prepared and their ratio and biogas potential is presented in Table 3. In the generation of biogas, the anaerobic digesters of pre-tanning waste category were not encouraging, and in this category the digester containing manure (FS5) only gave highest average volume $830 \pm 3.53 \mathrm{ml}$ (Table 3). Among digesters having different ratios of fats and shavings with manure, the digester with 1:3 (FS3) gave maximum biogas volume, which was $473 \pm 9.19 \mathrm{ml}$ on average (calculated on average of all replicas). The digester with a 1:1 (FS1) ratio of manure and pre-tanning waste gave $345 \pm 8.48 \mathrm{ml}$ average volume of biogas. The digester containing the waste at 1:2 (FS2) with manure gave $369 \pm 7.12 \mathrm{ml}$ of biogas. The anaerobic digester having pre-tanning waste gave no indication of biogas production throughout the experiment because there was no seedling to trigger the digestion process, and secondly the $\mathrm{pH}$ of this digester remained high even after monitoring at regular intervals. It is estimated that

Table 3. Assessment of Biogas production from fats and shavings of tannery waste.

\begin{tabular}{|c|c|c|}
\hline $\begin{array}{c}\text { Name of } \\
\text { digester }\end{array}$ & $\begin{array}{c}\text { Ratio of fats and } \\
\text { shavings with manure }\end{array}$ & $\begin{array}{c}\text { Average and standard } \\
\text { deviation of biogas (ml) }\end{array}$ \\
\hline FS1 & $1: 1$ & $345 \pm 8.48$ \\
\hline FS2 & $1: 2$ & $369.5 \pm 7.12$ \\
\hline FS3 & $1: 3$ & $473.5 \pm 9.19$ \\
\hline FS4 & $1: 0$ & 0 \\
\hline FS5 & $0: 1$ & $830.5 \pm 3.53$ \\
\hline
\end{tabular}

the biogas production efficiency of fats is higher than the shavings, carbohydrates and proteins because fats are chemical free, whereas shavings are tanned with salts that remain persistent even after the pre-treatment process and hence they hinder the biogas production efficiency of shavings as compared to the fats [22]. Adequate biogas formation from wastes requires a suitable carbon-nitrogen ratio. The inappropriate $\mathrm{C}-\mathrm{N}$ ratio results in biosynthesis of ammonia, which reduces biogas production from tannery solid waste [23]. In contrast, manure supplementation improved $\mathrm{C}-\mathrm{N}$ ratio and subsequent biogas formation. Our study corroborates with the similar investigations as reported by Moestedt et al. [24]. The sulphide contents present in pre-tanning tannery waste can also reduce the process of biogas formation. The hydrogen sulphide synthesized during biogas production can corrode a bioreactor and may cause environmental pollution [25]. From table 1 we see that fats have the highest value of $\mathrm{pH}$, but there alkaline nature is not persistent in anaerobic digestion whereas the shavings are alkaline on the second number but they have a persistent nature of $\mathrm{pH}$ along with requirement of long duration to be digested, and it makes them more alarming (as compared to fats) for inhibiting the process of anaerobic digestion [26]. The reason behind this factor is that the shavings had some persistent chemicals and its $\mathrm{pH}$ remained relatively high - even after timely and regular monitoring [27]. Shavings require special attention in maintenance of $\mathrm{pH}$ as they can rise due to methanogenesis and remnants of salts [28]. This low but persistent alkaline nature of shavings also baffled the biogas production potential of fats and manure, and resultantly the biogas yield remained low even in all combinations of fats and shavings with manure.

Correlation of pre-tanning waste (fats and shavings) and manure 1:1 (FS1), pre-tanning waste and manure 1:2 (FS2) and pre-tanning waste and manure 1:3 (FS3) showed that these variables are strongly correlated $(p<0.001)$ with each other in a two-tailed test. It is a well-documented fact that tannery solid waste (especially shavings) has higher collagen content. The higher quantity of collagen proteins in tannery shavings renders biogas production from tannery solid waste during anaerobic digestion [29].

\section{Biogas from Sludge with Respect of Retention Time}

The experiment on production of biogas from sludge remained very successful. Temperature and $\mathrm{pH}$ play a vital role in the anaerobic digestion process. Therefore, the digestion of sludge gave maximum values of biogas under mesophilic temperature and optimal $\mathrm{pH}$ range from 6.5 to 7.5. The graphical representation of biogas production per day is presented in Fig. 2. Higher gas generation was observed at $34^{\circ} \mathrm{C}$. Ariunbaatar et al. [30] also revealed that mesophilic conditions favour the bio-gasification of organic waste. 


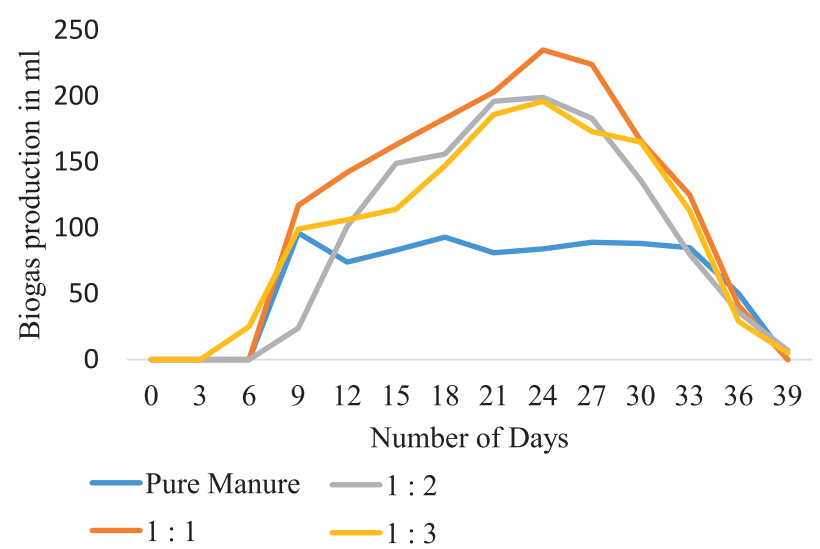

Fig. 2. Biogas production from sludge in different ratios with manure.

The digester sludge at 1:1 ratio with manure gave biogas yield from day 6 and initially until day 9 biogas production from the digester remained high at up to $120 \mathrm{ml}$. Among all digesters of sludge, the 1:1 ratio gave a high yield of biogas ascending up to $230 \mathrm{ml}$. The biogas production of the digester stopped at day 39 , and since the biogas was calculated after three days the calculation of accumulated biogas at the $39^{\text {th }}$ day was only $8 \mathrm{ml}$. The digester containing sludge in 1:2 (S2) with manure was second in biogas production. It showed biogas production at day 6, and the value of biogas was high at up to $100 \mathrm{ml}$ in its second reading at day 9. The digester with sludge at a 1:3 (S3) ratio with manure showed symptoms of biogas production at day 4 , but until day 6 the yield of biogas from this digester remained equal to the other digesters. The quantity of biogas from the digester containing only sludge was zero. The digester containing manure only also showed the symptoms of biogas at day 6 , and the yield of biogas from manure only remained low as compared to the other digesters of sludge. Leather industry sludge contains a considerable amount of organic contents that improve methanogenesis and biogas production from tannery sludge. Moreover, anaerobic digestion stabilizes the generation of biogas from bio-inoculated sludge of the leather industry. The combined anaerobic digestion of tannery sludge and cow dung synthesizes significantly higher quantities of methane and biogas [31].

\section{Biogas from Pre-Tanning Waste with Respect to Days}

The digester containing a 1:1 (FS1) ratio of pretanning waste (fats and shavings) and manure gave biogas production at day 6 and yield remained as low as $50 \mathrm{ml}$ even on the $9^{\text {th }}$ day. The maximum yield of biogas in this digester remained $55 \mathrm{ml}$. The digester containing a 1:2 (FS2) ratio of pre-tanning waste with manure remained even lower, ranging up to $43 \mathrm{ml}$ on the $9^{\text {th }}$ day. The peak value of produced biogas of this

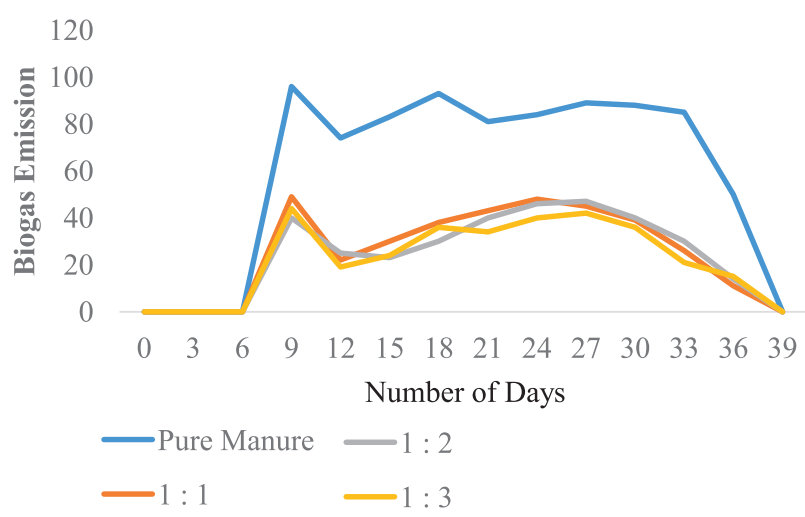

Fig. 3. Biogas value from pre-tanning waste and manure with respect of time.

digester remained at $50 \mathrm{ml}$ and no biogas was identified after the $39^{\text {th }}$ day of retention. Similarly, a digester of ratio 1:3 (FS3) of pre-tanning waste and manure showed symptoms of biogas on the $6^{\text {th }}$ day, and yield remained low (Fig. 3). The peak value of biogas in this digester was $45 \mathrm{ml}$. Above all, the digester of manure gave a high yield of biogas - even the first reading was near $100 \mathrm{ml}$ and peak value was calculated at $95 \mathrm{ml}$. In all digesters, no biogas was noticed after the $39^{\text {th }}$ day.

The study also sorted out a solution to the management of tannery solid waste and cow dung (which is problematic for the municipal committee) because the former takes longer to digest and the later decays openly in the air, prompting contamination of air but the combination of these two opens the door to their cost-effective and energy-efficient management.

\section{Analysis of Anaerobic Digester pH}

In the course of installation of the apparatus, every third digester was selected to measure $\mathrm{pH}$ using a digital meter accordingly. The range of $\mathrm{pH}$ in an anaerobic digester should be from 6.5 to 7.5 , strictly limiting the

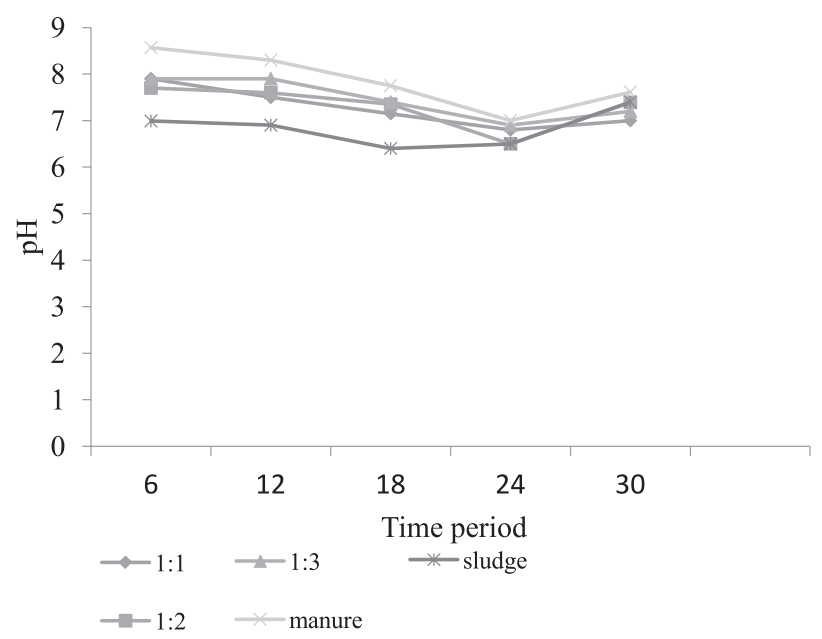

Fig. 4. Demonstration of $\mathrm{pH}$ variations in the sludge digesters. 


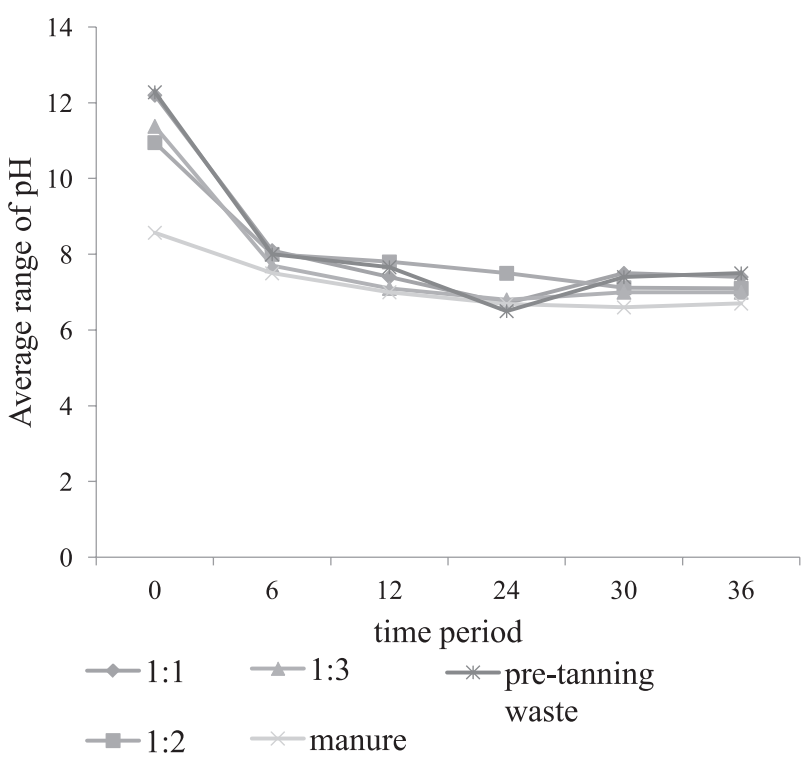

Fig. 5. Demonstration of $\mathrm{pH}$ variations in the digesters of pre-tanning (fats and shavings) waste.

range from 6.8 to 7.5 . The $\mathrm{pH}$ inside the digester should be monitored on regular intervals as it has a tendency to go up or down the limits by methanogenesis [32]. Variation in the $\mathrm{pH}$ range in an anaerobic digester of dried sludge was constantly changing, and every $6^{\text {th }}$ day was selected to measure the $\mathrm{pH}$ (Fig. 4), which shows that the $\mathrm{pH}$ value (measured before correction) remained above 7.5 and the resultantly low yield of biogas was achieved even after frequent correction. Similarly, during the $3^{\text {rd }}$ and $4^{\text {th }}$ reading intervals, $\mathrm{pH}$ was adjusted by adding diluted $\mathrm{H}_{2} \mathrm{SO}_{4}$ solution to all digesters. During this period, from days 18 to 30 , the peak values of biogas from $180 \mathrm{ml}$ to $230 \mathrm{ml}$ were achieved from the digesters of sludge in combination with manure.

\section{pH Variation in Pre-Tanning Waste Digester}

Pre-tanning waste comprising fats and shavings showed the alkaline nature of $\mathrm{pH}$ at large. The maximum $\mathrm{pH}$ value (before adjustment) reached 12.57 in FS3 (Fig. 5). The low biogas production from the anaerobic digesters of fats and shavings was the direct result of high $\mathrm{pH}$ value in the digesters, even after strict $\mathrm{pH}$ monitoring. Although the biogas production was started from the $6^{\text {th }}$ day in the digesters, it remained lower than the $50 \mathrm{ml}$ in only the digesters having combinations of pre-tanning waste with manure [33]. Analogous to the findings of this study, it has been demonstrated in a previous investigation that higher $\mathrm{pH}$ and low C:N cause ammonia toxicity, which reduces methane synthesis and subsequent biogas yield from tannery wastes during anaerobic digestion [34]. Since $\mathrm{pH}$ in the manure digester only remained optimal hence biogas yield was considerably high with a maximum value of $90 \mathrm{ml}$ at days $9,17-18$ and from $24-27$ in that digester.

\section{Conclusions}

The current study concludes that if $\mathrm{pH}$ (6.8 to 7.5) and temperature $\left(32-35^{\circ} \mathrm{C}\right)$ are maintained, the appropriate combination of waste from tanneries along with manure can produce biogas in just 39 to 40 days. The results showed that the dried sludge proved more feasible for biogas production as compared to pretanning waste. We found the highest yield of biogas from sludge in equal ratio to manure (S1) as compared to all samples designed for the study. However, fats and shavings are least suitable, as these can inhibit the production of biogas from manure because of their tendency toward $\mathrm{pH}$ variations. Many studies suggest that residual material from digesters can be used for domestic gardening. However, possible environmental issues related to pollutants generated during biogas generation from a combination of manure and tannery wastes must be elucidated and managed for establishing an eco-friendly energy source.

\section{Acknowledgements}

The authors are highly indebted to the laboratory staff and faculty of Government College University Lahore for their cooperation during the execution of our current research work.

\section{Conflict of Interest}

The authors declare no conflict of interest.

\section{References}

1. KAMESWARI S.B.K., KALYANARAMAN C., UMAMAHESWARI B., THANASEKARAN K. Enhancement of biogas generation during co-digestion of tannery solid wastes through optimization of mix proportions of substrates. Clean Technol Environ Policy, 16, 1067, 2014.

2. ZUPANČIČ G.D., JEMEC A. Anaerobic digestion of tannery waste: semi-continuous and anaerobic sequencing batch reactor processes. Bioresource Technol. 101 (1), 26, 2010.

3. BERHE S., LETA S. Anaerobic co-digestion of tannery waste water and tannery solid waste using two-stage anaerobic sequencing batch reactor: focus on performances of methanogenic step. J Mater Cycles Waste Managem. 1, 2018.

4. XU F., LI Y., GE X., YANG L., LI Y. Anaerobic digestion of food waste-challenges and opportunities. Bioresource Technol. 247, 1047, 2018.

5. MAVRODIN M., MOCANU C.R., GHEORGHELĂZĂROIU D.A., BONDREA B.N., CIPOLLONE R. Energy recovering from tanneries by biogas production. In $4^{\text {th }}$ International Conference of Thermal Equipment, Renewable Energy and Rural Development. 453, 2015. 
6. BAKONYI P., KOÓK L., KELLER, E., BELAFI-BAKO K., ROZSENBERSZKI T., SARATALE G.D., NGUYEN D.D., BANU J.R., NEMESTÓTHY N. Development of bioelectrochemical systems using various biogas fermenter effluents as inocula and municipal waste liquor as adapting substrate. Bioresource Technol. 259, 75, 2018.

7. GREGOR D., JEMEC Z.A. Anaerobic digestion of tannery waste: Semi-continues and implementation and enforcement of environmental law, Austria. 2010.

8. BRADLEY T., MERCY M. Potential to Produce Biogas from Tannery Waste. PAUWES Research-2-Practice Forum, 2018

9. KOUGIAS P.G., ANGELIDAKI I. Biogas and its opportunities-A review. Front Environ Sci Eng. 12 (3), 14, 2018. https://doi.org/10.1007/s11783-018-1037-8.

10. SCARLAT N., FAHL F., DALLEMAND J.F., MONFORTI F., MOTOLA V. A spatial analysis of biogas potential from manure in Europe. Renew Sustain Energ Rev. 94, 915, 2018.

11. VENUGOPALAN V., BALASUNDARAM N., HEMALATHA S. Comparative Study on Biogas Production from Cow Dung, Food Waste and Organic Wastes. Int J Civil Eng Technol. 8 (2), 100, 2017.

12. RAVINDRANATH E., CHITRA K., PORSELVAM S., SRINIVASAN S.V., SUTHANTHARARAJAN R. Green energy from the combined treatment of liquid and solid waste from the tanning industry using an upflow anaerobic sludge blanket reactor. Energy Fuels, 29, 1892, 2015.

13. CRĂCIUN I.M., VLAD G., IGNAT D., MOCANU R., BERKESY C.M., SOMEŞAN M. Leather industry waste material energetic valorisation by anaerobic digestion thanks to a Multi-Phase Process. AES Bioflux, 9 (1), 37, 2017.

14. AGUSTINI C.B., DA-FONTOURA J.T., MELLA B., GUTTERRES M. Evaluating co-substrates to supplement biogas production from tannery solid waste treatment - cattle hair, microalgae biomass, and silicone. Biofuels, Bioproducts Biorefining, 12 (6), 1095, 2018.

15. WALKER M., ZHANG Y., HEAVEN S., BANKS C.J. Potential errors in the quantitative evaluation of biogas production in anaerobic digestion processes. Bioresource Technol. 100 (24), 6339, 2009.

16. AGUSTINI C.B., MEYER M., DA-COSTA M., GUTTERRES M. Biogas from anaerobic co-digestion of chrome and vegetable tannery solid waste mixture: influence of the tanning agent and thermal pretreatment. Process Safety Environmental Protection, 2018.

17. OZGUNAY H., COLAK S., MUTLU M.M. AKYUZ F. Characterization of leather industry wastes. Polish J Environ Stud. 16 (6), 867, 2007.

18. KOKI I.B., JIMOH W.L.O. Assessment of heavy metals in tannery solid waste from Challawa Industrial Estate, Kano State, Nigeria. Int J Res Env Stud. 2 (2015), 33, 2015.

19. FRANCESCO F., CINZIA B. Biogas production from different Substrate in an experimental continuously stirred tank reactor anaerobic digester. J. Bioresource Technol. 100 (23), 5783, 2009

20. ESPOSITO G., FRUNZO L., PANICO A., PIROZZI F. Enhanced bio-methane production from co-digestion of different organic wastes. Environ technol. 33 (24), 2733, 2012.

21. FITAMO T.M. Systematic Quantification of Biogas Potential in Urban Organic Waste. Kgs. Lyngby: Technical University of Denmark, DTU Environment. 2017.

22. PESSUTO J., GODINHO M., DETTMER A. Biogas production from tannery wastes. Evaluation of isolated microorganisms effect. XXXIII IULTCS Congress November, $24^{\text {th }}-27^{\text {th }}$, Novo Hamburgo/Brazil. 1, 2015.

23. CHEN Y., CHENG J.J., CREAMER K.S. Inhibition of Anaerobic digestion Process: A review. Bioresource Technol. 99, 4044, 2008.

24. TAFIRENYIKA B., MANYUCHI M. Potential to Produce Biogas from Tannery Waste. 2018.

25. AL-MAMUN M.R., TORII S. Removal of hydrogen sulfide $\left(\mathrm{H}_{2} \mathrm{~S}\right)$ from biogas using zero-valent iron. J Clean Energ Technol. 3 (6), 1, 2015.

26. GOMES C.S., REPKE J.U., MEYER M. Diauxie during biogas production from collagen-based substrates. Renew Energ. 141, 20, 2019.

27. MOESTEDT J., MÜLLER B., WESTERHOLM M., SCHNÜRER A. Ammonia threshold for inhibition of anaerobic digestion of thin stillage and the importance of organic loading rate. Microbial Biotechnol. 9 (2), 180, 2016.

28. DIXIT S., YADAV A., DWIVENDI P.D., DAS M. Toxic hazards of leather industry and technologies to combat threat: a review. J Clean Prod. 87, 39, 2015.

29. PRIEBE G.P.S., KIPPER E., GUSMÃO A.L., MARCILIO N.R., GUTTERRES M. Anaerobic digestion of chrometanned leather waste for biogas production. J Clean Prod. 129, 410, 2016.

30. ARIUNBAATAR J., PANICO A., YEH D.H., PIROZZI F., LENS P.N., ESPOSITO G. Enhanced mesophilic anaerobic digestion of food waste by thermal pretreatment: Substrate versus digestate heating. Waste Managem. 46, 176, 2015.

31. AKYOL Ç., DEMIREL B., ONAY T.T. Recovery of methane from tannery sludge: the effect of inoculum to substrate ratio and solids content. J. Mater Cycles Waste Managem. 17 (4), 808, 2015.

32. DAMIJAN N. The anaerobic digestion of biodegradable tannery waste, Leather Journal. Anaerobic sequencing Batch reactor process. National Institute Of Chemistry, Laboratory for Environmental Sciences and Engineering, Ljubljana, Slovenia. 2009.

33. ELAMIN A.E., GASMELSEED G. Biogas Production from Tannery Liquid Waste. Eur J Eng Res Sci. 3, 117, 2018. DOI:https://doi.org/10.24018/ejers.2018.3.10.912.

34. SHANMUGAM P., HORAN N.J. Optimising the biogas production from leather fleshing waste by co-digestion with MSW. Bioresource Technol. 100 (18), 4117, 2009. 